\title{
Prevalensi dan Kepadatan Mikrofilaria pada Desa Non-Endemis Pasca Pengobatan Massal Tahun Keempat di Kabupaten Tanah Bumbu
}

\section{Prevalence and Density of Microfilaria in Non-Endemic Villages Post Fourth Year of Mass Treatment in Tanah Bumbu District}

\author{
Juhairiyah*, Dwi Candra Arianti, Erli Hariyati, Deni Fakhrizal, Paisal \\ Balai Penelitian dan Pengembangan Kesehatan Tanah Bumbu, Badan Litbang Kesehatan, \\ Kementerian Kesehatan RI \\ Kawasan Perkantoran Pemda Tanah Bumbu, Kabupaten Tanah Bumbu, Kalimantan Selatan, \\ Indonesia \\ *E_mail: ju2_juju@yahoo.com
}

Received date: 18-03-2020, Revised date: 13-07-2020, Accepted date: 11-11-2020

\begin{abstract}
ABSTRAK
Penelitian yang dilakukan di beberapa tempat di Indonesia menyebutkan pengobatan massal dapat menurunkan tingkat endemisitas filariasis. Kabupaten Tanah Bumbu telah melakukan pengobatan massal selama 4 tahun berturut-turut dengan hasil microfilaria rate pada desa sentinel menurun, namun masih terdapat penderita filariasis yang tidak meminum obat sehingga diperlukan penelitian pada desa spot lainnya di Kabupaten Tanah Bumbu untuk mengetahui keberhasilan POPM yang dilakukan. Penelitian ini merupakan studi observasional dengan desain potong lintang dilakukan di Desa Satiung/desa spot. Pengambilan jumlah sampel dilakukan berdasarkan aturan evaluasi pengobatan. Responden yang bersedia diambil darahnya akan diperiksa keberadaan mikrofilaria menggunakan metode mikroskopis dan Polymerase Chain Reaction (PCR) serta dilakukan tanya jawab menggunakan kuesioner tentang karakteristik dan kepatuhan responden terhadap POPM. Data dianalisis secara deskriptif dan disajikan dalam bentuk tabel dan grafik. Jumlah responden sebanyak 318 dengan karakteristik sebagian besar merupakan ibu rumah tangga dengan rentang usia produktif, persentasi responden meminum obat cukup tinggi yaitu sebesar 86,16\%, namun masih ditemukan responden tidak meminum obat yang dapat menyebabkan sumber penularan lebih lanjut. Hasil PCR ditemukan 2 sampel positif mikrofilaria Brugia malayi dari 318 sampel (Mf rate $=0,63 \%$ ), kepadatan rata-rata 116,9 dalam $1 \mathrm{ml}$ darah dengan satu penderita tidak rutin meminum obat setiap tahun. Perlu upaya peningkatan kepatuhan masyarakat terhadap POPM dengan melakukan penyuluhan dan pengawasan minum obat.
\end{abstract}

Kata kunci: filariasis, microfilaria rate, Brugia malayi, daerah non-endemis

\begin{abstract}
Research conducted at several places in Indonesia stated that mass treatment can reduce the level of endemicity of filariasis. Tanah Bumbu Regency has conducted mass treatment for 4 years in a row with the results of MF rate in sentinel villages decreased, However, there are still filariasis sufferers who do not take the drug so that research is needed in other spot villages in Tanah Bumbu Regency to determine the success of POPM. This study is an observational study with a cross-sectional design that was conducted at the Satiung/spot village. The sampling technique is based on treatment evaluation rules. Respondents who are willing to have their blood drawn will be examined for the presence of microfilaria using microscopic methods and polymerase chain reaction (PCR) and will be asked a questionnaire about the characteristics and compliance of respondents to POPM. Data were analyzed descriptively and presented in tables and graphs. Total respondents 318 with the characteristics are mostly housewives at a productive age range, the percentage of respondents taking drugs is quite high at $86.16 \%$, but still found the respondents did not take a medicine that can cause further infection source. PCR examination found 2 positive samples of Brugia malayi microfilaria from 318 samples (Mf rate = $0.63 \%$ ), the average density of 116.9 in $1 \mathrm{ml}$ of blood in one patient did not routinely take medicine every year. Efforts should be made to increase public compliance with POPM by conducting counseling and supervision on taking drugs.
\end{abstract}

Keywords: filariasis, microfilaria rate, Brugia malayi, non-endemic areas 


\section{PENDAHULUAN}

Filariasis limfatik atau filariasis adalah penyakit menular menahun yang disebabkan oleh mikrofilaria dan menginfeksi jaringan limfe (getah bening) ditularkan melalui gigitan nyamuk vektor. Jenis mikrofilaria yang menginfeksi manusia terbagi menjadi 3 yaitu Wuchereria bancrofti, Brugia malayi, dan Brugia timori. Penyakit ini tidak menyebabkan kematian namun dapat menyebabkan cacat permanen, trauma psikologis dan sosiologis, serta kerugian ekonomi karena pasien akan mengalami penurunan tingkat produktivitas. ${ }^{1,2}$ Filariasis dapat menyerang siapa saja baik pria, wanita dan anak-anak dari segala usia. ${ }^{3}$ Diperkirakan sebanyak 1,3 milyar penduduk di dunia berisiko tertular penyakit filariasis yang tersebar di 83 negara. Kawasan Asia Tenggara tercatat sebanyak $60 \%$ kasus filariasis, salah satunya di Indonesia, pada tahun 2017 terdapat sebanyak 12.677 kasus tersebar di 418 kabupaten/kota dan 34 provinsi. ${ }^{4}$ Sejak tahun 2005 diketahui angka microfilaria rate di Kabupaten Tanah Bumbu sebesar 2,35\%, angka tersebut menunjukkan bahwa Kabupaten Tanah Bumbu merupakan salah satu daerah endemis filariasis di Provinsi Kalimantan Selatan, dengan angka Mf rate > $1 \% .^{5}$

Berbagai upaya telah dilakukan pemerintah Kabupaten Tanah Bumbu, salah satunya membentuk komitmen dengan membuat surat pernyataan Bupati dan Ketua DPRD nomor 800/352/umum/2014 tentang Kesanggupan Pelaksanaan Program Eliminasi Filariasis di Kabupaten Tanah Bumbu dan tertuang dalam Renstra Dinas Kesehatan Kabupaten Tanah Bumbu dengan indikator angka $M f$ rate < $1 \%$. Selain itu, demi berhasilnya program eliminasi filariasis Kabupaten Tanah Bumbu telah melaksanakan pengobatan massal serentak satu kabupaten sejak tahun 2015. Kabupaten/kota yang dinyatakan endemis atau angka $M f$ rate $>1 \%$ wajib melakukan pemberian Obat Pencegahan secara Massal (POPM) serentak selama 5 tahun berturut-turut. ${ }^{6}$
Setelah dilakukan POPM, perlu dilakukan survei evaluasi prevalensi mikrofilaria untuk mengetahui prevalensi mikrofilaria (angka $M f$ rate) dan densitas mikrofilaria (kepadatan). Survei ini tidak dilakukan diseluruh wilayah desa/kelurahan, tetapi hanya dilakukan pada beberapa desa terpilih, yaitu ditetapkan di satu desa sentinel dan satu desa spot (spot check). Desa sentinel adalah desa terpilih sebagai desa data dasar prevalensi mikrofilaria sebelum pelaksanaan POPM filariasis atau desa endemis, dan tidak boleh diganti dengan desa lain. Desa spot dipilih diantara desa-desa yang masuk dalam daerah pelaksanaan POPM filariasis dan belum pernah dilakukan survei darah jari, survei data dasar prevalensi mikrofilaria dan survei evaluasi prevalensi mikrofilaria, terutama pada desa yang dicurigai berisiko masih terjadinya penularan filariasis, misalnya cakupan pengobatan rendah, faktor epidemiologi mendukung. ${ }^{6}$

Penelitian yang dilakukan di

Kelurahan Pabean, Kota Pekalongan menyebutkan bahwa pengobatan massal dapat menurunkan tingkat endemisitas filariasis. Hal tersebut juga disebutkan terbukti pada penelitian-penelitian lainnya, yang menyebutkan bahwa pengobatan massal terbukti efektif untuk menurunkan angka mikrofilaria. Untuk mengetahui penurunan angka mikrofilaria rate maka perlu dilakukan survei evaluasi pengobatan. ${ }^{7}$

Kepatuhan masyarakat meminum obat POPM merupakan faktor yang penting untuk melakukan eliminasi filariasis. ${ }^{7}$ Berdasarkan penelitian yang dilakukan di Desa Bilas, Kabupaten Tabalong, adanya penderita positif yang tidak meminum obat POPM dapat menularkan filariasis ke orang sehat lainnya. ${ }^{2}$ Berdasarkan penelitian yang dilakukan di desa sentinel Kabupaten Tanah Bumbu, pada tahun ke-3 pengobatan massal diketahui angka $M f$ rate telah terjadi penurunan namun masih ditemukan penderita filariasis karena tidak meminum obat rutin setiap tahun. ${ }^{5}$ Berdasarkan hasil tersebut dapat dicurigai 
terjadi penularan filariasis di daerah lainnya di Kabupaten Tanah Bumbu.

Belum pernah dilakukannya survei evaluasi pada desa spot lainnya di Kabupaten Tanah Bumbu, sehingga pada penelitian ini dilakukan evaluasi POPM pada desa tersebut. Tujuan penelitian untuk mengetahui angka microfilaria rate, kepadatan mikrofilaria, serta konfirmasi spesies mikrofilaria setelah pengobatan massal tahun ke 4 di Desa Satiung Kabupaten Tanah Bumbu.

\section{METODE}

Penelitian ini merupakan studi observasional dengan desain potong lintang. Penelitian ini merupakan kerjasama dengan Dinas Kesehatan Kabupaten Tanah Bumbu dengan nomor surat B/443.33/1038/ DinkesP2P.2/IV/2019. Data yang dikumpulkan adalah data darah jari serta karakteristik dan kepatuhan minum obat masyarakat. Pengumpulan data dilakukan pada bulan Mei 2019 pada desa spot filariasis di Kabupaten Tanah Bumbu, yaitu Desa Satiung yang dipilih sebagai desa spot dengan kriteria belum pernah dilakukan survei darah jari, survei data dasar prevalensi mikrofilaria dan survei evaluasi prevalensi mikrofilaria, epidemiologi yang mendukung dicurigai masih terjadinya penularan Filariasis. Populasi dan sampel untuk survei evaluasi prevalensi mikrofilaria berdasarkan Permenkes RI Nomor 94 Tahun 2014 tentang Penanggulangan Filariasis, yaitu minimal responden sebanyak 300 orang dengan sasaran batas umur $\geq 13$ tahun. Responden dikumpulkan pada tempat-tempat ibadah, rumah ketua RT, dan balai desa pada pukul 20.00. Pengambilan darah dilakukan pada pukul 21.00 waktu setempat. Jika responden belum mencapai target yang diinginkan, maka petugas pengambil darah akan melakukan pengambilan dengan cara kunjungan dari rumah ke rumah. Penduduk yang bersedia dijadikan responden akan ditusuk jarinya dan diambil darahnya sebanyak $60 \mu 1$, tetesan pertama dihapus menggunakan kapas, kemudian diteteskan lagi sebanyak 3 tetes pada kaca benda yang sudah disiapkan dan dilebarkan menggunakan kaca benda lainnya membentuk spesimen darah jari tebal berbentuk tiga garis paralel dengan masingmasing ukuran garis $0,5 \times 4 \mathrm{~cm} / 20 \mu 1$. Spesimen diwarnai menggunakan giemsa yang dilarutkan bersama cairan buffer $\mathrm{pH}$ 7,2 dengan perbandingan 1:20 dan diperiksa menggunakan mikroskop perbesaran 40x, kemudian dihitung prevalensi microfilaria rate (Mf rate) dan kepadatan mikrofilaria di dalam darah. $^{6}$

Perhitungan angka mikrofilaria ( $M f$ Rate) dilakukan dengan menggunakan rumus:

MF Rate $=\frac{\text { Jumlah Sediaan darah Positif Mikrofilaria }}{\text { Jumlah Sedian Darah yang diperiksa }} \times 100 \%$

Kepadatan rata-rata mikrofilaria dari hasil survei darah jari di satu desa adalah angka rata-rata mikrofilaria per mililiter darah, yaitu dengan menjumlahkan semua mikrofilaria yang ditemukan pada semua sediaan, dibagi dengan jumlah orang yang sediaannya positif mikrofilaria dikalikan faktor pengali (faktor pengali dari volume darah sampel yang diambil yaitu 16,7), seperti rumus berikut: ${ }^{6}$

$\frac{\text { Jumlah total mikrofilaria yang ditemukan }}{\text { Jumlah Slide positif mikrofilaria }}$ faktor pengali

Setelah diambil darahnya responden akan diwawancara tentang kepatuhan minum obat POPM. Hasil pemeriksaan darah yang positif mengandung mikrofilaria akan dilanjutkan dengan pemeriksaan menggunakan Polymerase Chain Reaction (PCR) yang dapat mendeteksi spesies 1 pikogram DNA filaria pada darah penderita.

Ekstraksi DNA dilakukan terhadap $300 \mu \mathrm{l}$ darah responden, menggunakan Wizard ${ }^{\circledR}$ Genomic DNA Purification Kit (PROMEGA). Sebanyak $2 \mu$ l hasil ekstraksi ditambahkan dengan $15 \mu \mathrm{l}$ Go Taq dan $1 \mu 1$ primer forward (5'GCGCATAAATTCATCAGC-3'), $\quad 1 \mu 1$ primer reverse (5'GCGCAAAACTTAATT ACAAAAGC-3'), dan $11 \mu 1$ nuclease free water $^{8}$ Campuran ini kemudian di PCR 
menggunakan Quant Studio 5 (Applied Biosystem, AS) dengan kondisi 1 siklus predenaturasi $95^{\circ} \mathrm{C}$ selama 1 menit, 35 siklus denaturasi $94^{\circ} \mathrm{C}$ selama 1 menit-annealing $59,6^{\circ} \mathrm{C}$ selama 1 menit-extension $72^{\circ} \mathrm{C}$ selama 1 menit, kemudian 1 siklus extension $72^{\circ} \mathrm{C}$ selama 10 menit, dan hold pada $4^{\circ} \mathrm{C}$. Produk PCR kemudian dielektroforesis pada agarose 1\%. Hasil positif jika terdapat pita dengan panjang $322 \mathrm{bp}$.

Responden yang dinyatakan positif pada penelitian ini akan dilaporkan kepada
Dinas Kesehatan Kabupaten Tanah Bumbu untuk dilakukan pengobatan selektif sesuai dengan dosis yang dianjurkan. Data dianalisis secara deskriptif dan disajikan dalam bentuk tabel dan grafik.

\section{HASIL}

Responden yang bersedia diambil darahnya dan diwawancara sebanyak 318 orang dengan karakteristik dan kepatuhan minum obat POPM dapat dilihat pada Tabel 1.

Tabel 1. Karakteristik Responden di Desa Satiung

\begin{tabular}{|c|c|c|}
\hline Karakteristik & $\mathrm{N}$ & Persentase $(\%)$ \\
\hline \multicolumn{3}{|l|}{ Jenis Kelamin : } \\
\hline Laki-Laki & 155 & 48,74 \\
\hline Perempuan & 163 & 51,26 \\
\hline \multicolumn{3}{|l|}{ Umur (thn): } \\
\hline$<13$ & 51 & 16,04 \\
\hline$\geq 13$ s.d. 65 & 259 & 81,44 \\
\hline$>65$ & 8 & 2,52 \\
\hline \multicolumn{3}{|l|}{ Pekerjaan: } \\
\hline Pelajar/ Mahasiswa(i) & 88 & 27,67 \\
\hline Petani/Tani/Bertani & 72 & 22,64 \\
\hline IRT & 93 & 29,25 \\
\hline Nelayan & 5 & 1,57 \\
\hline Penambang & 2 & 0,63 \\
\hline Perkebunan & 3 & 0,94 \\
\hline Swasta & 7 & 2,20 \\
\hline Wiraswasta & 7 & 2,20 \\
\hline PNS/Guru/Dokter/Bidan/Perawat/Honorer/PTT/Aparat Desa & 33 & 10,38 \\
\hline Belum Bekerja & 8 & 2,52 \\
\hline \multicolumn{3}{|l|}{ Keterangan Minum Obat } \\
\hline \multicolumn{3}{|l|}{ Meminum Obat : } \\
\hline Ya & 274 & 86,16 \\
\hline Tidak & 44 & 13,84 \\
\hline \multicolumn{3}{|l|}{ Meminum Obat Depan Petugas : } \\
\hline $\mathrm{Ya}$ & 142 & 44,65 \\
\hline Tidak & 176 & 55,35 \\
\hline \multicolumn{3}{|l|}{ Obat diminum Rutin Tiap Tahun : } \\
\hline Ya & 216 & 67,92 \\
\hline Tidak & 102 & 31,08 \\
\hline
\end{tabular}

Karakteristik responden berdasarkan jenis kelamin yang bersedia menjadi responden dalam penelitian ini hampir sama, dengan karakteristik umur dominan adalah usia produktif dan pekerjaan sebagai ibu rumah tangga (IRT). Walaupun persentase responden meminum obat cukup tinggi yaitu sebesar $86,16 \%$, namun masih terdapat sebesar
$13,84 \%$ responden tidak meminum obat dan sebesar $55,35 \%$ responden meminum obat tidak di depan petugas. Masih terdapat responden yang tidak meminum obat rutin setiap tahun, dengan alasan karena penyakit degeneratif.

Berdasarkan hasil pemeriksaan mikroskopis, ditemukan 2 orang positif 
mikrofilaria sehingga angka microfilaria rate di Desa Satiung sebesar 0,62\%, angka tersebut menyatakan bahwa Desa Satiung bukan merupakan desa endemis filariasis. Pada penderita A ditemukan 9 mikrofilaria dan penderita B terdapat 5 mikrofilaria sehingga kepadatan rata-rata mikrofilaria sebesar 116,9 dalam $1 \mathrm{ml}$ darah. Secara spesifik karakteristik dan kepatuhan penderita meminum obat filariasis dapat dilihat pada Tabel 2.

Tabel 2. Karakteristik Penderita Filariasis di Desa Satiung

\begin{tabular}{lcc}
\hline & & Penderita \\
\cline { 2 - 3 } Karakteristik & A & B \\
\hline Jenis Kelamin & Laki-laki & Perempuan \\
Umur & 18 thn & 40thn \\
Suku & Banjar & Banjar \\
Pendidikan & Tamat SLTA & Tamat SD \\
Pekerjaan & Tidak bekerja & Pedagang \\
Penghasilan & Rp.0,- & Rp.1.251.000,- s/d Rp.1.500.000,- \\
Lama tinggal & 18 thn & 40thn \\
Berpindah tempat tinggal & Tidak pernah & Tidak pernah \\
Menerima obat & Ya & Ya \\
Dimana memperoleh obat & Sekolah & Ada petugas datang ke rumah \\
Meminum obat & Ya & Ya \\
Rutin minum obat /patuh meminum obat & Ya & Tidak \\
Minum obat di depan petugas & Ya & Ya \\
Tahun memulai minum obat & 2015 & Lupa \\
Tidak rutin meminum obat & - & Hipertensi \\
Merasa efek samping obat & Ya & Ya \\
Efek yang dirasakan & Mengantuk & Sakit kepala, mengantuk, berdebar \\
Tindakan yang dilakukan setelah & Tidur & Minum obat sendiri \\
merasakan efek obat & & . \\
\hline
\end{tabular}

Diketahui jenis kelamin penderita yaitu laki-laki dan perempuan dengan usia produktif. Salah satu penderita merupakan pelajar, selalu meminum obat POPM yang diperoleh di sekolah dan selalu meminum obat tersebut di depan petugas, salah satu penderita lainnya merupakan pedagang yang tidak rutin meminum obat karena mempunyai riwat penyakit hipertensi. Kedua penderita merupakan penduduk asli yang berdasarkan pengakuan tidak pernah berpindah tempat selama masa hidupnya.

Berdasarkan hasil pemeriksaan mikroskopis menunjukkan jenis mikrofilaria yang menginfeksi mengarah pada jenis $B$. malayi. Standar emas untuk pemeriksaan mikrofilaria yaitu menggunakan mikroskop, namun pada penelitian ini juga dilakukan pemeriksaan menggunakan PCR karena pemeriksaan mikrofilaria menggunakan metode PCR dapat mendukung pemeriksaan secara mikroskopis terutama dalam penentuan spesies mikrofilaria. ${ }^{9}$ PCR mampu mendeteksi 1 pikogram DNA filaria pada darah penderita dan sensitif mendeteksi adanya DNA $B$. malayi dalam darah walaupun konsentrasinya sangat sedikit. ${ }^{8}$ Hasil pemeriksaan menunjukkan DNA spesies mikrofilaria yang menginfeksi kedua penderita yaitu B. malayi, seperti terlihat pada Gambar 1. 


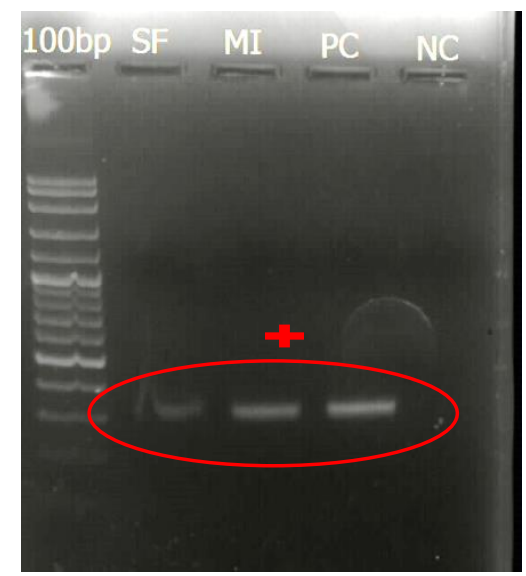

Keterangan :

$\mathrm{SF}=$ Penderita $\mathrm{B}$

$\mathrm{MI}=$ Penderita $\mathrm{A}$

$\mathrm{PC}=$ Kontrol Positif

$\mathrm{NC}=$ Kontrol Negatif

$100 \mathrm{bp}=$ Leader 100bp

Gambar 1. Hasil Pemeriksaan Mikrofilaria Menggunakan PCR

\section{PEMBAHASAN}

Desa Satiung yang terletak di Kecamatan Kusan Hilir sebenarnya bukan merupakan desa endemis, namun memiliki karakteristik epidemiologi yang hampir sama dengan Desa Binawara. Desa Satiung merupakan desa dengan jarak terjauh dari ibu kota kecamatan yaitu $25 \mathrm{~km}$ dengan waktu tempuh 1 jam 30 menit menaiki kapal motor karena merupakan daerah sekitar sungai. Selain merupakan desa terjauh, Desa Satiung juga merupakan desa terluas yaitu $73,61 \mathrm{~km}^{2}$ atau 18,3\% dari luas Kecamatan Kusan Hilir. Jumlah penduduk pada tahun 2018 sebesar 1.891 jiwa atau 2,24\% dari total penduduk di Kecamatan Kusan Hilir dengan jumlah lakilaki sebesar 947 jiwa dan perempuan 447 jiwa. Desa Satiung hanya memiliki 1 pusat pelayanan kesehatan yaitu poskesdes. ${ }^{9}$

Berdasarkan hasil penelitian di Desa Satiung ditemukan 2 orang positif mikrofilaria di dalam darahnya setelah pengobatan massal yang dilakukan selama 4 tahun berturut-turut dengan angka mikrofilaria rate sebesar $0,63 \%$. Walaupun angka microfilaria rate $<1 \%$ dan persentase responden yang meminum obat cukup tinggi, namun masih terdapat 13,84\% responden yang tidak meminum obat pencegah massal yang dibagikan dan sebanyak 31,08\% meminum obat tersebut tidak rutin setiap tahun, dengan kata lain responden tersebut tidak patuh meminum obat POPM. Penularan filariasis di suatu daerah dapat terus terjadi jika ditemukan nyamuk vektor dan rendahnya persentase kepatuhan penderita serta masyarakat yang tidak sakit meminum obat POPM secara teratur. ${ }^{2}$

Rendahnya kepatuhan masyarakat meminum obat dilaporkan diberbagai tempat terutama di India dengan alasan takut efek samping, tidak merasakan sakit filariasis sehingga tidak perlu minum obat, kurangnya kepercayaan akan khasiat obat, kader/tenaga kesehatan yang tidak datang ke rumah dan tablet yang diminum terlalu banyak. ${ }^{10,11} \mathrm{Hal}$ yang sama juga terjadi di Kabupaten Tabalong Provinsi Kalimantan Selatan, jawaban responden yang tidak mengonsumsi obat karena tidak tahu adanya pembagian obat dan takut akan efek obat tersebut. Kesadaran masyarakat yang kurang tentang peran POPM merupakan salah satu alasan utama ketidakpatuhan meminum obat POPM. Pengetahuan masyarakat tentang manfaat POPM harus diperkuat dengan persepsi, sikap, dan perilaku yang positif sehingga mengarah pada peningkatan kepatuhan meminum obat. ${ }^{2}$

Penelitian yang dilakukan Kulkarni dan kawan-kawan menyatakan bahwa salah satu faktor rendahnya kepatuhan masyarakat meminum obat adalah tidak efektifnya program KIE (Komunikasi, Informasi, dan Edukasi) yang dilakukan. Kegiatan KIE yang intensif diperlukan untuk meningkatkan 
pengetahuan dan meminimalkan kesalahpahaman masyarakat terhadap program POPM. ${ }^{10}$ KIE yang dilakukan salah satunya yaitu dengan penyuluhan kesehatan pada daerah-daerah endemis filariasis. Diperlukan strategi dalam komunikasi untuk penyuluhan filariasis diantaranya seperti yang dilakukan oleh Dinas Kesehatan Kabupaten Bogor yaitu dengan melakukan pemberdayaan masyarakat, bina suasana, advokasi, dan kemitraan. Namun berdasarkan hasil penelitian tersebut ditemui beberapa kendala dalam pelaksanaannya, diantaranya adalah kurangnya antusias warga dan kurangnya media promosi yang dilakukan dalam penyuluhan. ${ }^{12}$ Penyebaran informasi perlu dilakukan sesuai dengan media publik secara lokal di daerah tertentu. ${ }^{13}$

Penelitian yang dilakukan di Kota Depok dan Kabupaten Agam menyebutkan POPM harus dipromosikan sebagai kegiatan pencegahan, bukan sebagai pengobatan, untuk mencegah asusmsi masyarakat bahwa meminum obat tersebut hanya untuk mereka yang sakit. Serangkaian kegiatan yang dilakukan pada penelitian tersebut untuk meningkatkan kepatuhan masyarakat terhadap POPM pada Kabupaten Agam yaitu dengan melakukan pendekatan di sekolah, kantor pemerintah dan swasta, rumah tangga, serta pabrik untuk pelaksanaan POPM; media promosi digunakan, termasuk stiker pada kendaraan pemerintah, produksi selebaran serta spanduk; mendistribusikan obat pada tempat kerja seperti pabrik terutama untuk menjangkau penduduk dengan jenis kelamin laki-laki yang bekerja. Rangkaian kegiatan yang dilakukan di Kota Depok sedikit berbeda dengan yang dilakukan di Kabupaten Agam. Pendekatan pada kelompok pemangku kepentingan, polisi dan barak tentara yang terletak di kota, rumah sakit swasta dan pemerintah, perhimpunan bidan, perhimpunan dokter, serta LSM lokal untuk mempromosikan dan memfasilitasi POPM; kegiatan promosi yang mereka lakukan yaitu menggunakan billboard text pada jalan raya yang memuat pesan satu bulan sebelum dimulainya POPM dan acara radio serta pesan teks pada media sosial; pada bungkusan obat saat dibagikan disertakan selebaran kecil untuk informasi cara meminum obat, tentang keamanan obat, manfaat, efek samping, dan disediakan juga kontak informasi telepon untuk pengaduan atau untuk menjawab keresahan masyarakat yang langsung terhubung kepada petugas kesehatan. Pada kedua wilayah penelitian tersebut sama-sama melakukan pelatihan kepada petugas pembagi obat/kader untuk melakukan distribusi obat dengan benar dan dibekali diagram alur untuk beberapa informasi terhadap obat dan serangkaian pertanyaan serta tanggapan untuk membantu mereka dalam meyakinkan orang ini untuk menerima obat-obatan filariasis, selain kader para guru di sekolah juga bertanggungjawab untuk pendistribusian obat. ${ }^{14}$ Berdasarkan hasil penelitian, penderita memperoleh obat dari sekolah dan kader yang menandakan adanya usaha positif dari pemerintah Kabupaten Tanah Bumbu untuk meningkatkan cakupan pengobatan. Namun cakupan pengobatan saja tidak cukup mewakili bahwa masyarakat patuh meminum obat, sehingga diperlukan adanya pengawasan terhadap penderita dan masyarakat umum terhadap POPM dengan salah satunya meminum obat tersebut didepan petugas yang membagikan dan adanya upaya lain seperti yang dilakukan pada Kota Depok dan Kabupaten Agam.

Kepatuhan penderita filariasis meminum obat berdasarkan hasil penelitian menunjukkan penderita $\mathrm{A}$ selalu rutin minum obat POPM yang diperolehnya dari sekolah, namun masih terdapat mikrofilaria di dalam darahnya, belum selesainya rangkaian pengobatan yang dilakukan menyebabkan masih terdapatnya mikrofilaria di dalam darah penderita, karena diketahui penderita baru meminum obat 4 kali putaran. Masa hidup cacing dewasa filarial dapat bertahan selama \pm 5 tahun, sehingga obat POPM filariasis diminum selama 5 tahun berturut-turut dengan harapan setelah 5 tahun cacing dewasa tidak berkembang lagi dan mikrofilaria di dalam darah telah hancur serta tidak terjadi penularan 
lebih lanjut. Pengobatan massal satu siklus tidak dapat memutus rantai penularan infeksi langsung dari vektor ke hospes sehingga dibutuhkan pengobatan massal yang rutin setiap tahun untuk mengeliminasi secara komplit penularan mikrofilaria. ${ }^{5,8}$ Namun, hasil peneltian yang dilakukan di Kabupaten Muaro Jambi pada 3 desa wilayah penelitian angka $M f$ rate masih > $1 \%$ setelah dilakukan pengobatan massal selama 5 tahun berturutturut, hal yang sama juga terjadi di Kabupaten Tanjung Jabung Timur pengobatan massal dengan kombinasi diethylcarbamazine (DEC) dan albendazole yang dilakukan selama 2 tahap dinyatakan masih belum efektif karena belum menurunkan angka endemisitas. ${ }^{15}$

Pengobatan massal yang selama ini dilakukan dengan 2 kombinasi obat dilaporkan sejauh ini tidak dapat mengurangi prevalensi filariasis limpatik ke ambang batas target. ${ }^{15,16}$ Sebuah penelitian yang dilakukan, dengan membandingkan kombinasi pemberian obat filariasis yaitu dengan menambahkan ivermectin, hasil menunjukkan kombinasi 3 obat ivermectin, DEC, dan albendazole berpengaruh secara signifikan untuk mengurangi prevalensi filariasis, karena kombinasi ketiga obat tersebut menyebabkan sterilisasi atau pembunuhan cacing filaria dewasa secara permanen, jangka waktu lebih pendek terutama pada daerah dengan prevalensi tinggi. ${ }^{16}$ Penelitian lain juga dilakukan untuk mendukung target eliminasi filariasis tahun 2020 yaitu membandingkan dampak pemberian obat massal tahunan dan setengah tahunan pada prevalensi Brugia timori dan Wuchereria bancrofti di Pulau Flores. Prevalensi mikrofilaria menurun setelah lima kali perawatan setengah tahunan, sedangkan prevalensi mikrofilaria di dua desa lainnya menurun setelah tiga kali perawatan. Berdasarkan hasil penelitian di Pulau Flores tersebut menyatakan bahwa POPM tahunan cukup untuk mengurangi prevalensi mikrofilaria menjadi kurang dari $1 \%$ di daerah dengan baseline prevalensi rendah hingga sedang, sedangkan POPM setengah tahunan berguna untuk mengurangi prevalensi mikrofilaria dengan cepat di daerah dengan endemisitas awal yang lebih tinggi. ${ }^{17}$ Namun saran dari kedua penelitian tersebut belum mengubah kebijakan pemerintah yang diatur dalam PMK no 94 tentang Penanggulangan Filariasis yang masih menggunakan 2 kombinasi obat yaitu DEC dan albendazol dan pada daerah yang dengan endemis tinggi masih melakukan POPM 1 kali setahun.

Penderita B diketahui tidak rutin meminum obat POPM setiap tahun karena penyakit hipertensi, sesuai peraturan POPM, orang dengan riwayat hipertensi dan diabetes, usia di atas 65 tahun, wanita hamil dan menyusui merupakan kelompok yang tidak masuk dalam target pemberian POPM. $^{14}$ Kedua penderita diketahui merasakan efek samping setelah mengkonsumsi POPM, efek samping pengobatan dipengaruhi oleh kepadatan mikrofilaria di dalam darah. Semakin besar kepadatannya maka semakin besar efek samping yang ditimbulkan. ${ }^{2,9}$ Efek samping yang ditimbulkan oleh matinya mikrofilaria dalam darah akibat DEC menimbulkan keluhan demam, sakit kepala, pusing, nyeri otot, nyeri sendi dan tulang. ${ }^{2}$ Kepadatan rata-rata mikrofilaria di Desa Satiung sebesar 116,9 dalam $1 \mathrm{ml}$ darah dengan banyaknya mikrofilaria pada $60 \mu 1$ darah penderita A lebih banyak dari penderita $\mathrm{B}$, namun efek samping yang dirasakan penderita A lebih ringan dibandingkan penderita B. Hal tersebut karena penderita B memiliki riwayat penyakit hipertensi dan usia penderita yang lebih tua sehingga ketahanan tubuh untuk mengurangi efek samping obat lebih rendah dibandingkan penderita $\mathrm{A}$.

Jenis mikrofilaria yang menginfeksi kedua penderita berdasarkan pemeriksaan dengan metode mikroskopis mengarah kepada B. malayi yang kemudian dilanjutkan dengan menggunakan PCR hasil menunjukkan positif spesies B. malayi. Kegiatan kerjasama yang pernah dilakukan Laboratorium Parasitologi Balai Litbangkes Tanah Bumbu dan Dinas Kesehatan Kabupaten Tanah Bumbu pada tahun 2015 dilakukan pemeriksaan selama 24 jam pada 2 orang penderita di Desa Binawara 
dan Anjir baru ditemukan mikrofilaria $B$. malayi pada pukul 06.00 WITA. $^{18}$ Penelitian yang sama juga dilakukan di Kabupaten Tabalong Provinsi Kalimantan Selatan diketahui spesies B. malayi bersifat nonperiodik sehingga diperlukan kewaspadaan pada nyamuk vektor baik siang maupun malam hari. ${ }^{19}$ Berdasarkan pengakuan responden tidak pernah berpindah tempat tinggal sehingga dapat disimpulkan penularan terjadi ditempat penderita tinggal yaitu di Desa Satiung. Suatu daerah jika terdapat seseorang yang di dalam darahnya mengandung cacing filaria, dan di tempat tinggalnya terdapat nyamuk penular yang sesuai, maka daerah sekitarnya adalah daerah penularan. ${ }^{6}$ Kelemahan pada penelitian ini yaitu tidak melakukan survei entomologi untuk mengetahui vektor penular di Desa Satiung namun pernah dilakukan penelitian identifikasi vektor dan vektor potensial di Kabupaten Tanah Bumbu, yaitu Mansonia uniformis dan Culex quinquefasciatus. ${ }^{5,20}$ Jenis kelamin 2 orang penderita yaitu laki-laki dan perempuan, hal ini membuktikan bahwa filariasis dapat menularkan kepada siapa saja, baik laki-laki maupun perempuan dengan berbagai golongan usia. ${ }^{3,21}$

\section{KESIMPULAN}

Ditemukan 2 kasus positif mikrofilariasis pada desa nonendemis setelah pengobatan massal 4 tahun berturut-turut dengan angka $M f$ rate sebesar $0,63 \%$ dan kepadatan rata-rata mikrofilaria sebesar 116,9 dalam $1 \mathrm{ml}$ darah. Persentase responden meminum obat POPM cukup tinggi yaitu sebesar 86,16\%, namun masih terdapat $13,84 \%$ responden yang tidak patuh minum obat tiap tahun sehingga dapat mengakibatkan penularan lebih lanjut.

\section{SARAN}

Melanjutkan pengobatan massal tahun ke-5 serta melakukan upaya peningkatan cakupan kepatuhan pengobatan melalui pengawasan minum obat dan penyuluhan/promosi. Penyuluhan dilakukan dengan pemutaran video film atau pesan singkat melalui grup media sosial warga yang berisi pesan POPM filariasis.

\section{KONTRIBUTOR PENULIS}

J bertanggungjawab dalam semua aspek pembuatan tulisan. DCA dan EH bertanggungjawab dalam pengumpulan data dan pemeriksaan sampel. DF bertanggungjawab dalam format artikel dan revisi. $\mathrm{P}$ bertanggungjawab dalam koreksi dan menterjemahkan bahasa

\section{UCAPAN TERIMA KASIH}

Tim penulis mengucapkan terima kasih kepada Kepala Dinas dan Pengelola Program filariasis Dinas Kesehatan Kabupaten Tanah Bumbu atas kepercayaan dan kerjasamanya dalam pelaksanaan penelitian ini. Ucapan terima kasih juga kami sampaikan kepada Tim Laboratorium Parasitologi Balai Litbangkes Tanah Bumbu yang telah membantu dalam kegiatan penelitian ini.

\section{DAFTAR PUSTAKA}

1. Solikha I, Adi MS. Filariasis distribution and coverage of mass drug administration. J Berk Epidemiol. 2019;7(3):180-8. doi: 10.20473/jbe.v7i32019. 180-188.

2. Juhairiyah, Fakhrizal D, Hidayat S, Indriyati L, Hairani B. Kepatuhan masyarakat minum obat pencegah massal filariasis (kaki gajah): Studi Kasus Desa Bilas, Kabupaten Tabalong. J Vektor Penyakit. 2019;13(1):49-58.

3. Oguntolu F, Akinwande N, Alayiwola N, Faruq F. Semi analytical method for solving lymphatic filariasis epidemic model. J Appl Sci Environ Manag. 2019;23(2):233-40.

4. Prasetyowati H, Hodijah DN, Ipa M, Hendri J. Pengetahuan dan karakteristik individu: studi cakupan kepatuhan minum obat paska pemberian obat massal pencegahan filariasis di Kabupaten Tangerang. BALABA. 2019;(15)(2): 179-90. doi: 10.22435/blb.v15i2.1975.

5. Juhairiyah, Annida, Paisal, Rahayu N, Fakhrizal D. Evaluasi program Pemberian Obat Pencegah Massal (POPM) filariasis tahun ke 3 di Kabupaten Tanah Bumbu. Prosiding seminar nasional II Pascasarjana UNS; 2018 Okt 27. Solo: Pascasarjana Universitas Sebelas Maret; 
2018. p. 737-48.

6. Kementerian Kesehatan RI. Peraturan Menteri Kesehatan Repubik Indonesia Nomor 94 tahun 2014, tentang Penanggulangan Filariasis. Jakarta: Kementerian Kesehatan RI; 2015

7. Wahyudi BF, Pramestuti N. Kondisi filariasis pasca pengobatan massal di Kelurahan Pabean Kecamatan Pekalongan Utara Kota. BALABA. 2016;12(1):55-60.

8. Dalilah, Anwar C, Theodorus, Saleh I. Identifikasi spesies nyamuk genus Mansonia dan deteksi molekuler terhadap mikrofilaria/larva cacing Brugia malayi pada nyamuk genus Mansonia. J Kedokt Dan Kesehat. 2017;4(2):69-75.

9. Santoso, Suryaningtyas NH. Spesies mikrofilaria pada penderita kronis filariasis secara mikroskopis dan Polymerase Chain Reaction (PCR) di Kabupaten Tanjung Jabung Timur. Media Litbangkes. 2015;25(4):294-56.

10. Kulkarni P, Thomas JJ, Dowerah J, Narayana Murthy MR, Ravikumar K. Mass drug administration programme against lymphatic filariasis-an evaluation of coverage and compliance in a northern Karnataka district, India. Clin Epidemiol Glob Heal. 2020 Mar 1;8(1):87-90. doi:10.1016/j.cegh.2019.04.013.

11. Shuford KV, Turner HC, Anderson RM. Compliance with anthelmintic treatment in the neglected tropical diseases control programmes: a systematic review. Parasit Vectors. 2016;9(29):1-16. doi: 10.1186/s13071-016-1311-1.

12. Candrasari S, Naning S. Strategi komunikasi persuasif Dinas Kesehatan Kabupaten Bogor dalam penyuluhan penyakit kaki gajah. J Bisnis dan Komun. 2019;6(1):80-8.

13. Paisal, Rahayu N, Annida. Perilaku minum obat massal filariasis di Desa Pihaung dan Bajang, Kabupaten Hulu Sungai Utara. SEL J Penelit Kesehat. 2019;6(2):90-100.
14. Krentel A, Damayanti R, Titaley CR, Suharno $\mathrm{N}$, Bradley M, Lynam T. Improving coverage and compliance in mass drug administration for the elimination of LF in two 'endgame' districts in Indonesia using micronarrative surveys. PLoS Negl Trop Dis. 2016;10(11):e0005027. doi: 10.1371/journal.pntd.0005027.

15. Santoso, Yenni A, Oktarina R, Wurisastuti T. Efektivitas pengobatan massal filariasis tahap II menggunakan kombinasi DEC dengan Albendazole terhadap prevalensi Brugia malayi. Bul Penelit Sist Kesehat. 2015;18(2):161-8.

16. Irvine MA, Stolk WA, Smith ME, Subramanian S, Singh BK, Weil GJ, et al. Effectiveness of a triple-drug regimen for global elimination of lymphatic filariasis: a modelling study. Lancet Infect Dis. 2020;17(4):451-8. doi: 10.1016/S1473-3099(16)30467-4.

17. Supali T, Djuardi Y, Lomiga A, Linda SN, Iskandar E, Goss CW, et al. Comparison of the Impact of annual and semiannual mass drug administration on lymphatic filariasis prevalence in Flores Island, Indonesia. Am J Trop Med Hyg. 2019;100(2):336-43. doi: 10.4269/ajtmh.18-0570.

18. Laboratorium Parasitologi Balai Litbang P2B2 Tanah Bumbu. Laporan Laboratorium Parasitologi Balai Litbang P2B2 Tanah Bumbu. Tanah Bumbu: Balai Litbang P2B2 Tanah Bumbu; 2015.

19. Juhairiyah, Ridha MR, Fakhrizal D. Periodesitas non periodik Brugia Malayi di Kabupaten Tabalong. Vektora. 2017;9(2):7986.

20. Safitri A. Laporan penelitian identifikasi vektor dan vektor potensial daerah endemis filariasis di Kalimantan Selatan Tahun 2011 [Laporan Akhir Penelitian]. Tanah Bumbu: Balai Litbang P2B2 Tanah Bumbu; 2011.

21. Ferlianti R, Pratiwi HPG, Adria F, Ravidian WF, Devi FF, Haniyah H. Hubungan faktor lingkungan fisik dalam dan luar rumah dengan kejadian filariasis di Jatisampurna Bekasi. J Kedokt Yars. 2018;26(1):1-11. 